\section{Æresmedlem Hans Henrik Holm døde den 24. juli 2016}

NFUD kondolerer og deler sorgen om et stort menneske og en fremragende forsker og lærer. Hans Henrik Holm var æresmedlem i vår forening. Hans liv og virke omtales av DUDS (Dansk Ultralyddiagnostisk Selskab) i oktober utgaven av Ultraschall

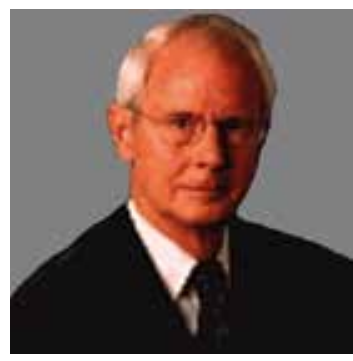

Hans Henrik

Holm

in der Medizin - European Journal of Ultrasound (Ultraschall in Med 2016; 37(05): 540) 